\title{
NETIZEN COMMENTS ON PRESIDENT JOKO WIDODO'S INSTAGRAM POST: A CRITICAL DISCOURSE ANALYSIS
}

BY:

\section{NURBANI SYIFA ${ }^{1}$, DIDIN NURUDDIN HIDAYAT ${ }^{2}$ (UIN SYARIF HIDAYATULLAH JAKARTA ${ }^{1,2}$ )}

\begin{abstract}
Social criticism is one form of communication in the society that aims or functions as a control of the course of a system or process of society. Instagram has been perceived as one of the most popular social media today. One of the focuses of this research is on one of the photos that President JokoWidodo brought up in his Instagram account. The study aims to examine how the form of social criticism delivered by netizens made in the comments column uploaded by President JokoWidodo. This study employed a qualitative approach to analysis. The data analysis technique used in this study was based on the theory put forward by Teun A Van Dijk'sCritical Social Discourse Analysis. The results of this study found the the background and knowledge of social netizens regarding Jokowi's presidential in the vocabularies of the comments they wrote, and their comments that stimulated other comments from other netizens.
\end{abstract}

\section{Keywords: Critical Discourse Analysis, Instagram, Netizen's Comments}

\section{INTRODUCTION}

The term discourse analysis is a general term used in many scientific disciplines and with various meanings. In linguistic studies, discourse refers to a complete unitary language, which is generally greater than a sentence, both delivered in oral or in writing. Discourse is a series of harmonious sentences that connect the proportions of one and the other, sentences with one another, and thus form a unity. The unity of language can be either long or short. As a text, discourse is not a sequence of sentences that do not have ties to one another, not times that are just lined up. Discourse analysis relates to the study of language use(Brown \& Yule, 1983).

Social media has gained an interest in the world of research, and a significant number of previous studies have explored on the issues surrounding 
social media (e.g., Moghadam et al., 2015; Putra \& Triyono, 2018; Ratnasari et al., 2019; Turhan, 2017; Yousefi \& Rostami, 2019). Some of them raised a theme or one of the interesting social media, or a different point of views(Lee \& Watkins, 2016; Safira et al., 2019; Upadhyay, 2018). Theresearcherschose the construction of the discourse on Instagram comments with a critical paradigm.

Social media Critical Discourse Analysis is a form of conclusion from the point of view expressed by the netizen on the message conveyed President JokoWidodo in one of his posts on Instagram, which is in contact with the subject of content analysis, framing analysis, discourse, and semiotics. Hegemony and dominant ideological impact conveyed in the comments(Fairclough, 1995). Netizens also have a variety of backgrounds and knowledge of the president's posts we can see in terms of the language spoken by netizens in the comments column.

Discourse analysis relates to the study of language/language use. To explain more about discourse analysis, we need to ask how is language seen in discourse analysis?The existence of three analytical paradigms are used to view language(Brown \& Yule, 1983; Hikam, 1996). The first view is represented by the Positivism - Empirical. Adherents of this understanding see language as a bridge between humans and objects outside themselves. The human experience is considered to be directly expressed through the use of language without any constraints data distortion, so far as it is expressed by using logical statements, syntax, and has a relationship with empirical experience. One characteristic of this thinking is the separation between ideas/thoughts and reality. Concerning discourse analysis, the logical consequence of this understanding is that people do 
not need to know the subjective meanings or values that underlie their statements, because what is important is whether the statement is correctly stated according to the syntactic and seeming rules. Therefore, syntactic truth (grammar) is the main field of positivism flow about discourse.

The second view in discourse analysis is Constructivism. This view is much influenced by phenomenological thinking. This flow rejects the view of positivism/empiricism in discourse analysis that separates subject and language objects. In the view of constructivism, language is no longer only seen as a tool for understanding objectives reality that is separated from the subject as a statement conveyer. Constructivism thus assumes that the subject is the main actor or a central factor in the activities of discourse and social relationships.

The third view is called a critical view. The view is to correct the viewpoint of constructivism that is less sensitive to the production process and the reproduction of meaning that has happened historically and institutionally. Constructivism is still not analyzing the factors of internal power relations in each discourse, which in turn play a role in forming certain types of subjects and their behaviors. This is what gives birth to a critical paradigm.

This writing is intended as a reference to the comments of the Instagram user, which leads to a critical paradigm to examine the existing background of the commentator following what they wrote in the column. The researchers hope to examine the power of the text further and find concepts that attract the power of netizens, as well as uncover hidden meanings with a critical view of the discourse.This research study aims to answer two research questions: (1) What is the background and knowledge of social netizens regarding Joko Widodo's 
Instagram posting in the vocabularies of the comments they wrote? (2) What is the modality of their comments that stimulate other comments from netizens?

\section{RESEARCH METHODOLOGY}

This part addresses the research design, procedure, participants, instrument, and data collection procedure. A qualitative research design was chosen for this research because the methodology best allowed the researcher to collect the data to answer the research questions.

The researchers conducted a qualitative data analysis design. Data were analyzed using T. A. Van Dijk (2016;1997; 1999)to describe the discourse analysis. To enrich the analysis material also touched on discourse and ideological understanding in the media byFowler (1991), with a case of analyzing netizen comments on PresidentJokoWidodo's post.

The sample data were taken from several comments from Presidents JokoWidodo's Instagram post on 30 October 2018. In his post, he wrote about the tragedy of Lion Air JT-610.

Serpihanpesawatdanbarang-barangmilikpenumpang Lion Air JT-610 yang diangkatdarilautdandievakuasikeTanjungPriok, Jakarta, sore tadi.Denganmengerahkanlebih $30 \quad$ kapaldanhelikopter, parapenyelamdariBasarnas Special Group, Kopaskhas, dan unit lain, timgabungansaatinitengahbekerjakerasmelakukanpencarianbadanpesawat , kotakhitam, danparakorban.Mohondoadariseluruh Tanah Air untukkelancarandankemudahanpekerjaanini.

This post explains the photo of President JokoWidodo, who was visiting the TanjungPriok Port, Jakarta, to see the results of the progress of the evacuation of officers on the incident of Lion Air JT-610. 


\section{RESULT AND DISCUSSION}

This paper would like to describe the discourse analysis model of Teun A van Dijk,to enrich the analysis of materials also alluded to understanding the discourse and ideology.

According to Van Dijk (1999), discourse analysis research is not enough based solely on text analysis, because the text is only the result of a production practice. Understanding the production of text will eventually gain knowledge of why text can be like that. Van Dijk also looks at how social structures, domination, and groups of power exist in society and how cognitions/thoughts and consciousness form and influence specific texts.

In the picture and caption written by President Joko Widodo on 30 October, 2018, for example. On his Instagram, President Joko Widodo uploaded a photo of him carrying out an evacuation of Lion Air JT-610 and accompanied by a caption:

Serpihanpesawat dan barang-barangmilikpenumpang Lion Air JT-610 yang diangkatdarilaut dan dievakuasikeTanjungPriok, Jakarta, sore tadi. Denganmengerahkanlebih 30 kapal dan helikopter, para penyelamdariBasarnas Special Group, Kopaska, dan unit lain, timgabungansaatinitengahbekerjakerasmelakukanpencarian badan pesawat, kotakhitam, dan para korban.Mohon doadariseluruh Tanah Air untukkelancaran dan kemudahanpekerjaanini.

Pieces of the plane and passengers' belongings of Lion Air JT-610 is lifted from the sea and evacuated to TanjungPriok, Jakarta, this afternoon. By deploying over 30 ships and helicopters, divers from the Special Group Basarnas, Kopaskhas, and other units, the joint team is currently working hard to search the fuselage, a black box, and the victims. We humbly request prayers of the whole country for smoothness and ease of this work.

The post made by Jokowi invited 7,821 comments from netizens who were asked in several ways and perspectives. The researchers took three perspectives from netizens, which corroborated the theory of Dijk (1999). First, refining the 
concepts and definitions concerned with power. This omission has two pro and contra perspectives on Jokowi's current leadership and the political period in 2019. For example, the word represented by hashtags such as \#2019gantipresident and \#jokowi2period hashtag. Below are some netizen comments that reinforce this theory.

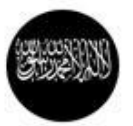

adhisya21 Katanya kangen didemo.. Giliran didemo malah kabur.. Kan sontoloyo... \#2019gantipresiden

\section{$6 \mathrm{~m}$ Balas}

Figure 1.1

The comments in the picture above mean,"He said he missed the demonstration ... The demonstration was turned away instead ... \# 2019 depends on the president." The comments made by the Instagram account named @adhisya21 were subtle delivery to the person who contested Jokowi.

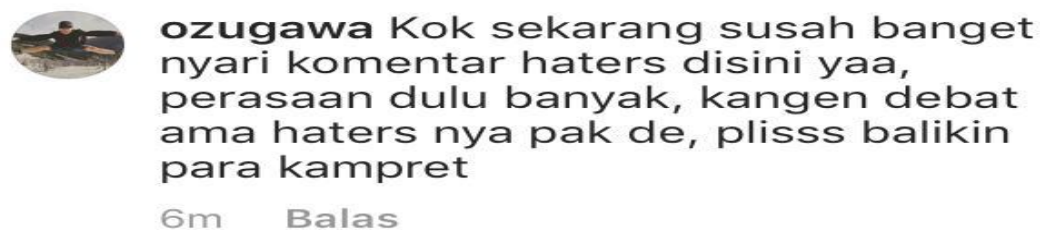

\section{Figure 1.2}

An account called @ozugawa sent a sentence that had the meaning "Now it's really hard to find comments haters here, miss the debate with the haters, Sir". These comments subtly corner those who counter President Joko Widodo.

Second, targeting aims to corner other forces that will threaten power or position, such as the elements of SARA or criticisms related to the caption written by Mr. Joko Widodo. Below is one example: 


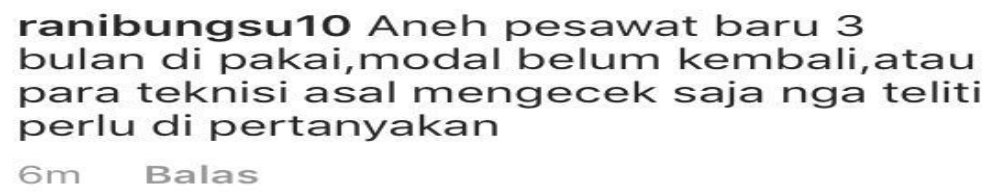

Figure 1.3

The comments written by the @ ranibungsu10 Instagram account mean,"Strangely, the plane has only been used for three months. The capital has not returned, or the technicians from checking it out need to be questioned". Secondly, Lion Air, in the context of the writing written by Mr. President Jokowi, is as a main idea in writing. Whereas in real life, Lion Air is one of the major airline businesses in Indonesia. The comments made by @ ranibunhsu10 severely cornered the airline, which caused a threat of decline in the development of the Lion Air airline business.

Third, the theory presented by Dijk (1999) the creation of words that can incite and provoke people's emotions as some comments invite the emotions of other netizens. Usually, comments written from contra parties to President Joko Widodo.

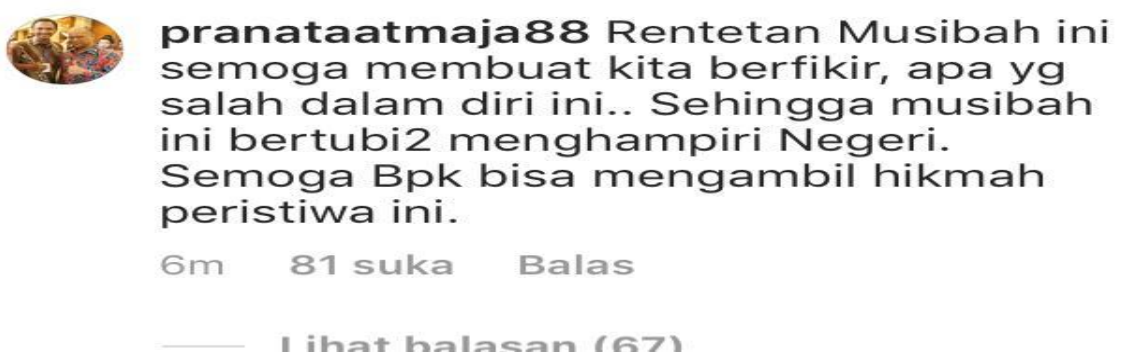

Figure 1.4

Another sample comment was written by an Instagram account named @ pranataatmaja88. The comments he wrote means "This sequence of tragedy may 
make us think, what is wrong with this, so that this tragedy insistently toward the country. Hopefully, you can take the lesson from this tragedy". This comment invites 67 comments from netizens.

\section{CONCLUSION}

The study has found that netizens' comments as a response to President Joko Widodo's post on Instagram consist of three (3) broad areas. The first one is the response that deals with the relation of the political agenda in the period of 2019. The next is that the comments also attempt to corner President Joko Widodo and was used to critics his policies. Further, the last category applies to incite and provoke other emotions from the netizens who are pro and contra toward President Joko Widodo. Future similar research studies can deal with larger data so as to provide a more comprehensive understanding toward the phenomenon happening on social media.

\section{REFERENCES}

Brown, G., \& Yule, G. (1983). Discourse Analysis. Cambridge Textbooks in Linguistics. UK : Cambridge University Press.

Fairclough, N. (1995). Critical discourse analysis: The critical study of language. Longman.

Fowler, R. (1991). Language in the News: Discourse and ideology in the press. London and New York: Routledge.

Hikam, M. A. S. (1996). Bahasa dan politik: Penghampiran discursive practice. Bandung : Mizan.

Lee, J. E., \& Watkins, B. (2016). YouTube vloggers' influence on consumer luxury brand perceptions and intentions. Journal of Business Research, 
69(12), 1-8. https://doi.org/10.1016/j.jbusres.2016.04.171

Moghadam, S., Ladan, Kasraie, K., \& Mansour. (2015). The investigation of the relationship between imagination from brand's suitability and brand preference Active brand detergent consumers in Sanandaj City. International Letters of Social and Humanistic Sciences, 53, 112-116.

https://doi.org/10.18052/www.scipress.com/ilshs.53.112

Putra, H. P., \& Triyono, S. (2018). Critical Discourse Analysis on Kompas.Com News: "Gerakan \#2019Gantipresiden.” LEKSEMA: Jurnal Bahasa Dan Sastra, 3(2), 113-121. https://doi.org/10.22515/ljbs.v3i2.1412

Ratnasari, D., Hidayat, D. N., Alek, A., \& Defianty, M. (2019). Interpersonal Meaning Analysis of Indonesian Politicians ' Instagram Captions. Advances in Social Science, Education and Humanities Research, 408, 222-230.

Safira, A., Putri, D. W., \& Wattimena, G. H. (2019). Self presentation beauty influencer Abel Cantika via Youtube. Profetik Jurnal Komunikasi, 12(1), 3045.

Turhan, B. (2017). Critical Discourse Analysis of Advertising: Implications for Language Teacher Education. International Journal of Languages' Education, 1(Volume 5 Issue 4), 213-226. https://doi.org/10.18298/ijlet.2301

Upadhyay, S. (2018). A conceptual model incorporating Twitter as a language tool in ESL/EFL learning. TESOL International Journal, 13(4), 49-54.

Van Dijk, T. A. (2016). Critical discourse analysis. Revista Austral de Ciencias Sociales, 2016, 30, 203-222.

Van Dijk, Teun A. (1997). Critical discourse analysis. In Discourse as structure and process of discourse studies: A multidisciplinary introduction: Vol. I. SAGE Publications.

Van Dijk, Teun A. (1999). Context models in discourse processing. The Construction of Mental Representations During Reading, 123-148.

Yousefi, M. H., \& Rostami, F. (2019). A Critical Discourse Analysis of the representations of females in printed advertisements (Case study of Payame Yaghoot Medical Health Iranian Journal). The Journal of Applied Linguistics and Applied Literature: Dynamics and Advances, 7(1), 35-45. https://doi.org/10.22049/jalda.2019.26392.1103 